\title{
KARAKTERISTIK KIMIA DAN POTENSI DAUN TANAMAN AKAR BULOU (MIKANIA MICRANTHA KUNTH) SEBAGAI OBAT LUKA TRADISIONAL
}

\author{
CHEMICAL CHARACTERISTICS AND POTENTIAL OF AKAR BULOU \\ (MIKANIA MICRANTHA KUNTH) LEAVES AS TRADITIONAL WOUND \\ HEALING
}

\author{
Oleh: \\ Andrian Fernandes ${ }^{1}$, Rizki Maharani ${ }^{1}$, Sigit Sunarta ${ }^{2}$, dan Rayan ${ }^{1}$ \\ ${ }^{1}$ Balai Besar Penelitian dan Pengembangan Ekosistem Hutan Dipterokarpa Samarinda \\ Jalan A.W. Syahranie No.68, Sempaja, Samarinda Telp. (0541) 206364 Fax, (0541) 42298 \\ ${ }^{2}$ Jurusan Teknologi Hasil Hutan, Fakultas Kehutanan, Universitas Gadjah Mada \\ Jalan Agro No. 1, Bulaksumur, Yogyakarta \\ af.andrian.fernandes@gmail.com; rizma_annisa@yahoo.com
}

Diterima 18-09-2018, direvisi 26-11-2018, disetujui 03-12-2018

\begin{abstract}
ABSTRAK
Tanaman Bulou (Mikania micrantha Kunth) merupakan salah satu jenis gulma yang sangat mudah tumbuh dan menyebar. Masyarakat desa Nyapa Indah, Berau, Kalimantan Timur, mengenal tanaman ini dengan sebutan Akar Bulou dan telah menggunakan daunnya sebagai obat luka alami. Pengembangan daun tanaman Akar Bulou sebagai obat luka tradisional perlu mendapat dukungan uji ilmiah. Oleh karena itu, dalam studi ini dilakukan uji ilmiah beberapa karakteristik kimia meliputi uji fitokimia, uji akti oksidan dan senyawa aktifnya agar memperkuat potensi pemanfaatannya sebagai obat luka alternatif. Hasil uji menunjukkan bahwa daun tanaman Akar Bulou mengandung alkaloid, triterpenoid dan steroid. Pada ekstrak Akar Bulou larut etanol 95\% memiliki bioaktifitas antioksidan tertinggi pada konsentrasi 25 ppm sebesar 83,31\%. Sedangkan untuk senyawa aktifnya, terdapat senyawa alkaloid yang diduga terdapat dalam daun tanaman Akar Bulou adalah 2(Dimethylamino)-1,3-dimethyltetrahydro-1,3,2-diazaphosphole 2-oxide. Sedangkan Bicyclo[7.2.0]undec-4ene, 4,11,11-trimethyl-8-methylene tergolong dalam terpenoid yang merupakan senyawa metabolit sekunder untuk membantu dalam proses penyembuhan luka.
\end{abstract}

Kata Kunci: Mikania micrantha Kunth, Akar Bulou, Gulma, karakteristik kimia, obat luka

\section{ABSTRACT}

Akar Bulou (Mikania micrantha Kunth) plants is one of weed species that is very easy to grow and spread out. Community of Nyapa Indah, Berau, East Kalimantan called this plant as Akar Bulou and Akar Bulou leaves have been used as a natural wound healing. The development of Akar Bulou leaves as traditional wound healing needs to be supported by scientific tests. Therefore, in this study scientific tests were carried out on several chemical characteristics including phytochemical tests, oxidant activity tests and their active compounds (GC-MS analysis) in order to strengthen their potential use as alternative wound healing. Results showed that the leaves of Akar Bulou contained alkaloids, triterpenoids and steroids. Akar Bulou extracted by ethanol 95\% soluble has highest antioxidant bioactivity at a concentration of 25 ppm (83.31\%). While, the active compound is alkaloid compounds which are thought to be present in Akar Bulou leaves are 2(Dimethylamino) -1,3-dimethyltetrahydro-1,3,2-diazaphosphole 2-oxide. Whereas Bicyclo [7.2.0] undec-4 ene, 4,11,11-trimethyl-8-methylene belongs to terpenoids which are secondary metabolites for assist in wound healing processes.

Keywords: Mikania micrantha Kunth, Akar Bulou, weed, chemical characteristics, wound healing 


\section{PENDAHULUAN}

Luka terbuka yang terjadi pada manusia dapat mengakibatkan tingkat kematian yang signifikan (Wong et al, 2011). Oleh karena itu adanya luka pada tubuh manusia harus segera diobati dan disembuhkan. Proses penyembuhan luka hingga saat ini masih menjadi masalah klinis yang terus dilakukan penyempurnaan (Cakrabarti et al, 2016).

Di masa kini, pengobatan luka menggunakan bahan alami semakin berkembang dan popular (Fitzmaurice et al, 2011). Salah satu obat luka alami yang telah dikenal dan digunakan di dusun Nyapa Indah, Berau, Kalimantan Timur adalah Akar Bulou (Mikania micrantha Kunth). Tumbuhan Akar Bulou ( $M$ micrantha Kunth) merupakan jenis tanaman gulma yang dapat tumbuh dengan mudah dan menyebar cepat (Huang et al, 2012). Oleh karena itu, ketersediaannya sangat melimpah sehingga dengan mudah masyarakat dapat mamanfaatkannya sebagai penyembuh luka. Berdasarkan informasi dari pengobat tradisional warga dusun Nyapa Indah, untuk mengobati luka, daun Akar Bulou diambil sekitar 7 atau 9 lembar dan diasapi. Setelah agak layu ditempelkan ke bagian yang luka. Jumlah daun yang digunakan harus ganjil dan menyesuaikan dengan ukuran luka yang ada.

Untuk mengembangkan obat luka berbasis obat tradisional perlu didukung pengujian secara ilmiah, diantaranya adalah uji fitokimia, uji senyawa aktif dan uji antioksidan
(Georgescu et al, 2016). Salah satu sifat obat luka alami berbahan herbal harus memiliki sifat antioksidan yang baik (Pareta et al, 2015).

Beberapa penelitian tentang $M$ micrantha Kunth telah digunakan sebagai bioherbisida (Hamidah et al, 2015), antibakteri (Alfiah et al, 2015) dan antirayap (Salam et al, 2014), sedangkan penelitian kegunaan $M$ micrantha Kunth sebagai bahan obat luka belum dilakukan. Penelitian ini bertujuan untuk mengetahui komponen fitokimia, menduga kandungan kimia menggunakan GC-MS dan mengetahui bioaktivitas antioksidan dari Akar Bulou yang berpotensi sebagai obat luka.

\section{METODOLOGI PENELITIAN}

\subsection{Preparasi Contoh Uji}

Daun Akar Bulou Mikania micrantha Kunth (family Asteraceae) diambil dari kebun warga Nyapa Indah, Labanan, Berau, Kalimantan Timur, dengan titik koordinat $\mathrm{N} 01^{\circ} 52^{\prime} 48.3^{\prime \prime}$ dan E $117^{\circ} 18^{\prime}$ 01.7". Daun yang diperoleh dikering-anginkan dan dibawa ke laboratorium Teknologi Hasil Hutan, Balai Besar Penelitian dan Pengembangan Ekosistem Hutan Dipterokarpa (B2P2EHD).

\subsection{Maserasi daun Akar Bulou}

Akar Bulou kering angin diblender. Proses maserasi mengacu pada metode yang diadopsi dari Fernandes et al (2018). Serbuk diayak dengan saringan 40-60 mesh. 100 gram serbuk selanjutnya direndam dalam $100 \mathrm{ml}$ etanol $95 \%$ selama 24 jam pada suhu kamar. Rendaman 
kemudian disaring dan filtrat yang diperoleh dipekatkan hingga $10 \mathrm{ml} .5 \mathrm{ml}$ ekstrak pekat digunakan untuk uji fitokimia dan $5 \mathrm{ml}$ lainnya digunakan untuk uji GC-MS.

\subsection{Pengujian fitokimia}

Ekstrak pekat dipipet $1 \mathrm{ml}$ ke dalam tabung reaksi, kemudian dilarutkan dalam $14 \mathrm{ml}$ etanol. Uji fitokimia yang dilakukan mengacu pada metode yang dikemukakan oleh Harborne (1998) dan Kokate (2001). Pengujian fitokimia dilakukan di laboratorium Kimia Hasil Hutan, Fakultas Kehutanan, Universitas Mulawarman.

\section{a. Pengujian alkaloid (Kokate, 2001).}

Identifikasi dilakukan dengan menggunakan larutan Dragendorff. Tahapan pembuatan larutan Dragendorff sebagai berikut:

- Larutan I : 0,5 g bismut (III) nitrat $+6 \mathrm{ml}$ asam asetat dan $24 \mathrm{ml}$ aquades.

- Larutan II : 12 g kalium iodida $+30 \mathrm{ml}$ aquades.

- Larutan I + larutan II (1 ml : $1 \mathrm{ml})$

- $1 \mathrm{ml}$ larutan campuran ditambah $2 \mathrm{ml}$ asam asetat dan $10 \mathrm{ml}$ aquades, selanjutnya larutan siap untuk digunakan.

Sebanyak $5 \mathrm{ml}$ ekstrak ditambahkan $2 \mathrm{ml}$ $\mathrm{HCl}$, kemudian dimasukkan $1 \mathrm{ml}$ larutan Dragendorff. Perubahan warna larutan menjadi jingga atau merah mengindikasikan bahwa ekstrak mengandung alkaloid.

\section{b. Pengujian Flavonoid (Kokate, 2001)}

Sebanyak $1 \mathrm{ml}$ ekstrak diberikan beberapa tetes natrium hidroksida encer $(\mathrm{NaOH} 1 \%)$. Munculnya warna kuning yang jelas pada larutan ekstrak dan menjadi tidak berwarna setelah penambahan asam encer $(\mathrm{HCl} 1 \%)$ mengindikasikan adanya flavonoid.

\section{c. Pengujian Saponin (Harbone, 1998)}

Pengujian dilakukan dengan memasukkan sebanyak $10 \mathrm{ml}$ air panas ke dalam tabung reaksi yang berisi $1 \mathrm{ml}$ sampel uji yang telah dilarutkan dalam etanol. Selanjutnya larutan didinginkan dan dikocok selama 10 detik. Terbentuknya buih mantap selama kurang lebih 10 menit dengan ketinggian $1-10 \mathrm{~cm}$ dan tidak hilang bila ditambahkan 1 tetes $\mathrm{HCl}$ 2N menandakan bahwa ekstrak yang diuji mengandung saponin.

\section{d. Pengujian Tanin (Kokate, 2001)}

Pengujian dilakukan dengan memasukkan $10 \mathrm{ml}$ larutan ekstrak ke dalam tabung reaksi dan ditambahkan larutan timbal asetat $(\mathrm{CH} 3 \mathrm{COO}) 2 \mathrm{~Pb} 1 \%$. Tanin dinyatakan positif apabila pada reaksi terbentuk endapan kuning.

\section{e. Pengujian Triterpenoid dan steroid (Harbone, 1998)}

Identifikasi dilakukan dengan menggunakan campuran asam asetat anhidrid dan asam sulfat pekat yang biasa dikenal dengan pereaksi LiebermannBurchard.

Pada pengujian ini 10 tetes asam asetat anhidrid dan 2 tetes asam sulfat pekat ditambahkan secara berurutan ke dalam $1 \mathrm{ml}$ 
sample uji yang telah dilarutkan dalam aseton. Selanjutnya sampel uji dikocok dan dibiarkan beberapa menit. Reaksi yang terjadi diikuti dengan perubahan warna, apabila terlihat warna merah dan ungu maka uji dinyatakan positif untuk triterpenoid dan apabila terlihat warna hijau dan biru maka uji dinyatakan positif adanya steroid.

\subsection{Pengujian Antioksidan}

Uji antioksidan tumbuhan obat dilakukan dengan metode DPPH (1,1-diphenyl-2picrylhydrazil) (Herawati et al., 2011). Ekstrak tumbuhan obat dilarutkan dalam metanol dan dibuat dalam berbagai konsentrasi 200, 100, 50 dan 25 ppm. Masing-masing dimasukkan dalam tabung reaksi dan ditambahkan $500 \mu \mathrm{l}$ larutan DPPH $1 \mathrm{mM}$ dalam metanol. Volume dicukupkan sampai $5 \mathrm{ml}$, kemudian diinkubasi pada suhu $37^{\circ} \mathrm{C}$ selama 30 menit, selanjutnya serapannya diukur pada panjang gelombang $517 \mathrm{~nm}$. Serapan kontrol ditentukan dengan mengganti sampel metanol. Sebagai kontrol positif digunakan vitamin $\mathrm{C}$.

\subsection{Pengujian GC-MS}

Pengujian GC-MS mengikuti metode yang digunakan oleh Maharani et al (2016). GC-MS (Shimadzu QP 2010: jenis kolom adalah RTx5MS (Restek Corp.) dengan panjang $30 \mathrm{~m}$, suhu injektor dan detektor $250^{\circ} \mathrm{C}$, dan suhu operasi $50-300^{\circ} \mathrm{C}$.

Kenaikan suhu pada $50-120^{\circ} \mathrm{C}$ diatur dengan laju kenaikan suhu $4^{0} \mathrm{C} /$ menit ditahan selama 1 menit kemudian suhu $120-300^{\circ} \mathrm{C}$ dengan laju kenaikan suhu $6{ }^{\circ} \mathrm{C} /$ menit kemudian ditahan selama 5 menit pada suhu tersebut dengan waktu retensi $(R t)$ total mencapai 60 menit. Gas pembawa: Helium, kisaran berat molekul 50-500. Kuantifikasi pendugaan senyawa diperoleh dari pembacaan area pada grafik GCMS. Pendugaan senyawa hasil uji GC-MS dilakukan dengan menggunakan software Wiley/NIST Library.

\section{HASIL DAN PEMBAHASAN}

Maserasi Akar Bulou dengan etanol 95\% memiliki rendemen $2,01 \%$. Hasil uji fitokimia menunjukkan bahwa daun Mikania micranta Kunth mengandung alkaloid, triterpenoid dan steroid.

Castro et al (1986) menyebutkan bahwa jenis-jenis Mikania mengandung senyawa diterpena dan sesquiterpen. Bakir et al (2004) mengidentifikasikan senyawa mikanolide sebagai salah satu jenis sesquiterpen yang dapat diisolasi dari daun Mikania micrantha. Sedangkan Gutierrez dan Herz (1988) menyatakan bahwa senyawa kimia dalam daun Mikania shushunensis mengandung senyawa benzene, biasanya disertai gugus alkohol.

Dalam studi ini, diduga senyawa Bicyclo[7.2.0]undec-4-ene, 4,11,11-trimethyl8-methylene terkandung dalam ekstrak etanol Akar Bulou sebanyak 6,95\%. Bicyclo[7.2.0]undec-4-ene, 4,11,11-trimethyl8-methylene dikenal juga dengan nama isocaryophyllene dan tergolong dalam kelompok terpenoid. Barreto et al (2014) menyebutkan bahwa senyawa dalam kelompok terpenoid 
adalah salah satu senyawa metabolit sekunder yang membantu dalam proses penyembuhan luka.

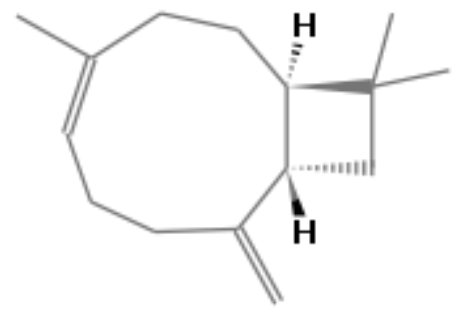

Gambar 1. Bicyclo[7.2.0]undec-4-ene, 4,11,11trimethyl-8-methylene.

Figure 1. Bicyclo[7.2.0]undec-4-ene, 4,11,11trimethyl-8-methylene.

Reyes et al (1993) mengemukakan bahwa alkaloid, seperti senyawa taspine, akan mempercepat fase awal penutupan luka terbuka dengan cara memacu terbentuknya fibroblast sehingga sel darah merah akan berhenti keluar dari luka. Sedangkan untuk keberadaan steroid diprediksi akan membantu dalam proses penutupan luka dengan cara membantu pembentukan sel kulit baru pada bagian luka terbuka (Gilliver dan Ashcroft, 2007).

Kelompok alkaloid memiliki atom nitrogen (N) pada senyawa kimianya (Zhao et al, 2018). Dari hasil pengujian GC-MS, diduga senyawa alkaloid yang terkandung dalam ekstrak etanol Akar Bulou terlihat pada tabel 1.

Tabel 1. Senyawa kimia kelompok alkaloid. Table 1. Alkaloid chemical compounds.

\begin{tabular}{lc}
\hline $\begin{array}{l}\text { Senyawa Kimia } \\
\text { Chemical compound }\end{array}$ & $\begin{array}{c}\text { Konsentrasi (\%) } \\
\text { Concentration (\%) }\end{array}$ \\
\hline Pyridine-3-carboxylic & 5,05 \\
acid, 1,4-dihydro-5- & \\
cyano-2-hydroxy-4-(4- & \\
isopropylphenyl)-6- & \\
methyl-, ethyl ester & \\
\hline
\end{tabular}

\begin{tabular}{ll}
\hline $\begin{array}{l}\alpha \text {-Acetyl-N,N- } \\
\text { dinormethadol }\end{array}$ & 6,41 \\
\hline $\begin{array}{l}\text { 2-(Dimethylamino)- } \\
\text { 1,3-dimethyltetrahydro- } \\
\text { 1,3,2-diazaphosphole 2- } \\
\text { oxide }\end{array}$ & 5,74 \\
\hline $\begin{array}{l}\text { Oxazolidin-2-one, 3- } \\
\text { tert-butyl-5- } \\
\text { phenoxymethyl- }\end{array}$ & \\
ethanone, 1-(4- \\
pyridinyl)-, oxime
\end{tabular}

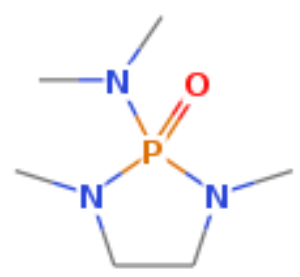

Gambar 2. 2-(Dimethylamino)-1,3dimethyltetrahydro-1,3,2-diazaphosphole 2-oxide. Figure 2. 2-(Dimethylamino)-1,3dimethyltetrahydro-1,3,2-diazaphosphole 2-oxide.

Pyridinil oximes dalam Ethanone, 1-(4pyridinyl)-, oxime merupakan gugus fungsional yang berfungsi untuk membentuk polimer secara kompleks dan memiliki sifat gaya tarik seperti magnet (Zuo, 2018). Adanya ikatan antar senyawa etanon membentuk suatu jaring yang menghambat sel darah merah keluar dari luka. Vinaya et al (2009) 2-[4-(2,4-dimethoxybenzoyl)-phenoxy]-1-[4-(3-piperidin-4-ylpropyl)-piperidin-1-yl]-ethanone menunjukkan efek signifikan pada penyembuhan luka hewan uji tikus albino. 


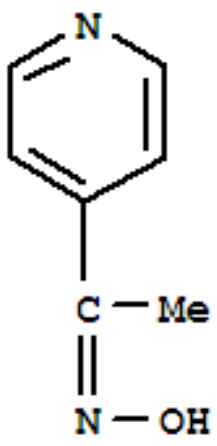

Gambar 3. Ethanone, 1-(4-pyridinyl)-, oxime.

Figure 3. Ethanone, 1-(4-pyridinyl)-, oxime.

Tabel 2. Bioaktivitas antioksidan.

Table 2. Antioxidant bioactivity.

\begin{tabular}{lllll}
\hline Contoh uji & \multicolumn{4}{c}{ Antioksidan (\%) } \\
Sample & \multicolumn{4}{c}{ Antioxidant (\%) } \\
\cline { 2 - 5 } & 200 & 100 & 50 & 25 \\
& ppm & ppm & ppm & ppm \\
\hline Akar & 49,61 & 50,78 & 70,92 & 83,31 \\
Bulou & & & & \\
\hline Vitamin C & 96,14 & 97,08 & \\
\hline
\end{tabular}

Pada ekstrak Akar Bulou larut etanol 95\% memiliki bioaktifitas antioksidan tertinggi pada konsentrasi 25 ppm sebesar 83,31\%. Sebagai perbandingan, Arun et al (2016) ekstrak etanol daun Jasminum auriculatum dengan konsentrasi 33,39 $\mu \mathrm{g} / \mathrm{ml}$ memberikan bioaktivitas antioksidan tertinggi sebagai bahan obat luka. Pareta et al (2015) menyebutkan bahwa adanya sifat antioksidan yang tinggi akan mencegah kerusakan sel dan membantu pembentukan jaringan epitel pada luka. Penelitian ini merupakan penelitian pendahuluan, sehingga perlu dilakukan isolasi senyawa aktif yang lebih murni dan penerapannya pada uji pra-klinis maupun uji klinis.

\section{KESIMPULAN}

Hasil uji fitokimia pada daun Akar Bulou Mikania micranta Kunth) menunjukkan sejumlah kandungan senyawa alkaloid, triterpenoid dan steroid di dalam sampel uji. Senyawa alkaloid akan mempercepat fase awal penutupan luka terbuka dengan cara memacu terbentuknya fibroblast. Keberadaan steroid diprediksi akan membantu dalam proses penutupan luka dengan cara membantu pembentukan sel kulit baru pada bagian luka terbuka. Sedangkan senyawa yang merupakan golongan terpenoid merupakan salah satu senyawa metabolit sekunder yang dapat membantu dalam proses penyembuhan luka.

Bioaktifitas antioksidan pada ekstrak Akar Bulou larut etanol 95\% sebesar 83,31\% dengan konsentrasi $25 \mathrm{ppm}$. Hal ini menunjukkan bahwa dengan sifat antioksidan yang tinggi kerusakan sel akan dapat dicegah karena adanya pembentukan jaringan epitel baru pada luka.

Pengujian pada penelitian ini dapat digunakan sebagai dasar penelitian lanjutan untuk memperkuat potensi pemanfaatan daun Akar Bulou sebagai obat luka tradisional. Sehingga tanaman Akar Bulou yang merupakan tanaman pengganggu (gulma) dapat dikendalikan, bahkan dapat dijadikan sebagai peluang ketersediaan bahan baku penyembuh luka alternatif secara berkesinambungan.

\section{UCAPAN TERIMA KASIH}

Tulisan ini didedikasikan untuk Bapak Amiril Saridan yang telah banyak membantu 
dalam identifikasi botani tumbuhan obat. Penulis juga menyampaikan ucapan terima kasih terhadap masyarakat dusun Nyapa Indah, Berau, Kalimantan Timur, yang telah banyak membantu dalam pencarian bahan tumbuhan obat yang dipergunakan dalam studi ini.

\section{DAFTAR PUSTAKA}

Alfiah, RR, S. Khotimah dan M. Turnip. 2015. Efektivitas Ekstrak Metanol Daun Sembung Rambat (Mikania micrantha Kunth) Terhadap Pertumbuhan Jamur Candida albicans. Protobiont. 4 (1) : 52-57.

Arun, M, S Satish dan P Anima. 2016. Evaliation of Wound Healing, Antioxidant and Antimicrobial Efficacy of Jasminum auriculatum Vahl. Leaves. Avicenna Journal of Phytomedicine. 6 (3) : 295-304.

Bakir, M., P. C. Facey, I. Hasan, W. H. Mulder dan R. B. Porter. 2004. Mikanolide from Jamaican Mikania micrantha. Journal of Acta cryst. Vol. c60.Hal. O798-O800.

Barreto, RSS, RLC Albuquerque Jr, AAS Araujo, JRGS Almeida, MRV Santos, AS arreto, JM deSantana, PSS Lima, JSS Quintans dan LJQ Junior. 2014. A Systematics Review of the Wound Healing Effect of Monoterpenes and Iridoid Derivatives. Molecules journal. 19 (1) : 846-862. Doi : 10.3390/molecules19010846.

Castro, V., J. Jakupovic dan F. Bohlmann. 1986. Sesquiterpene Lactones from Mikania Species. Phytochemistry Journal. 25 (7) : 1750-1752. Cakrabarti, SK, R Bhattacharya dan KD Deb. 2016. Cell-based Wound Healing : Mechanisms and
Treatments. British Journal of Medicine \& Medical Research. 11 (4) : 1-17.

Fernandes, A, R. Maharani dan Supartini. 2018. Analisis Fitokimia dan GC-MS Daun Ungu Kucing (Eupatorium odoratum L.F.) Sebagai Bahan Obat Aktif. Jurnal Penelitian Ekosistem Hutan Dipterokarpa. 4 (1) : 1-8.

Fitzmaurice, SD, RK Sivamani dan RR Isseroff. 2011. Antioxidant Therapies for Wound Healing: a Clinical Guide to Currently Commercially Available Products. Skin Pharmacology and Physiology Journal. 24 : 113-126.

Georgescu, M, O Marinas, M Popa, T stan, V Lazar, SV Bertesteanu dan MC Chifiriuc. 2016. Natural Compounds for Wound Healing. Worldwide Wound Healing - Innovation in Natural and Conventional Methods. doi : $10.5772 / 65652$.

Gutierrez, A. B., dan W. Herz. 1988. Bisabolones and Other Constituents of Mikania shushunensis. Phytochemistry Journal. 27 (12) : 3871-3874

Gilliver, S. C. dan G. S. Ashcroft. 2007. Sex Steroids and Cutaneous Wound Healing : the Contrasting Influences of Estrogens and Androgens. Climacteric Journal. 10 : 276-288. Hamidah, HS, Mukarlina dan R Linda. 2015. Kemampuan Ekstrak Daun Sembung Rambat (Mikania micrantha H.B.K) Sebagai Bioherbisida Gulma Melastoma affine D. Don. Protobiont. 4 (1) : 89-93.

Herawati, N., N. Jalaluddin, La Daha dan F. Zenta. 2011. Potensi Antioksidan Ekstrak Metanol Kulit Batang Tumbuhan Mangrove Sonneratia alba. Majalah Farmasi dan Farmakologi. 15 (1) : 23-25. 
Huang, YL, XT Fang, L Lu, YB Yan, SF Chen, L Hu, CC Zhu, XJ Ge dan SH Shi. 2012. Transcriptome Analysis of an Invasive Weed Mikania micrantha. Biologia Plantarum. 56 (1) : 111-116.

Kastika, SM dan R Rahayu. 2018. Pengaruh Formula Obat Herbal Untuk Penyembuhan Luka bakar. Jurnal Bioprospek. 13 (1) : 26-32. Maharani, R., A. Fernandes, M. Turjaman, G. Lukmandaru dan H. Kuspradini. .2016. The Characterization of Phytochemical and Gc-Ms Analysis on Borneo Agarwood (Aquilaria malaccensis Lamk) Leaves and Its Utilization as an Anti-Browning in Apple Juice. International Journal of Pharmacognosy and Phytochemical Research. 8 (10) : 1576-1582.

Pareta, JK, GK Sharma dan N Shrivastav. 2015. Wound Healing and Antioxidant Activity of Polyherbal Formulation. Lambert Academic Publishing.

Reyes, B. H. P., W. H. Lewis, J. Roman, L. Simchowitz dan T. A. Mustoe. 1993. Enhancement of Wound Healing by the Alkaloid Taspine Defining Mechanism of Action. Experimental Biology and Medicine Journal. 18-25.

Salam, DM, Mukarlina dan F Diba. 2014. Pengendalian Rayap Tanah Coptotermes curvignathus Holmgren Menggunakan Ekstrak
Daun Gulma Sembung Rambat (Mikania micrantha Kunth). Protobiont. 3 (2) : 87-92.

Vinaya, K, HR Naika, CSA Kumar, SBB Prasad, S Chandrappa, SR Ranganatha, V Krishna dan KS Rangappa. 2009. Evaluation of in Vivo Wound-healing Potential of 2-[4-(2,4dimethoxy-benzoyl)-phenoxy]-1-[4-(3piperidin-4-yl-propyl)-piperidin-1-yl]Ethanone Derivates. European Journal of Medicinal Chemistry. 44 (8) : 3158-3165.

Wong, VW, M Sorkin, JP Glotzbach, MT Longaker dan GC Gurtner. 2011. Surgical to Create Murine Models of Human Wound Healing. Journal of Biomedicine and Biotechnology. doi:10.1155/2011/969618.

Zhao, B., JY zhao, SS sagdullaev dan H Aisa. 2018. Diterpene Alkaloids from Aconitum smirnovii. Chemistry of Natural Compounds Journal. 54 (4) : 828-830.

Zuo, J. 2018. Crystal Structure of Aqua (1-(21pyridyl) Etanone Oxime- $\left.\mathrm{K}^{2} \mathrm{~N}, \mathrm{~N}^{\prime}\right)(1-(2-$ pyridyl) Ethanone Oximato-K $\left.{ }^{2} \mathrm{~N}, \mathrm{~N}^{\prime}\right)$ Nitrate Monohydrate, $\mathrm{C}_{14} \mathrm{H}_{19} \mathrm{~N}_{5} \mathrm{O}_{7} \mathrm{Cu}$. NCS Journal. doi : 10.1515/ncrs-2017-0336. 